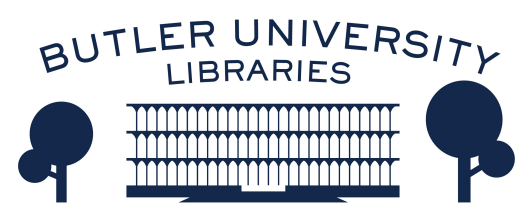

Journal of Hindu-Christian Studies

Volume 25

Article 7

November 2012

\title{
Toward a Fusion of Theological Horizons: Constructivist Reflections and Responses to the Question of Theism in the Yoga Sutra
}

Graham M. Schweig

Follow this and additional works at: https://digitalcommons.butler.edu/jhcs

Part of the Religion Commons

\section{Recommended Citation}

Schweig, Graham M. (2012) "Toward a Fusion of Theological Horizons: Constructivist Reflections and Responses to the Question of Theism in the Yoga Sutra," Journal of Hindu-Christian Studies: Vol. 25, Article 7.

Available at: https://doi.org/10.7825/2164-6279.1513

The Journal of Hindu-Christian Studies is a publication of the Society for Hindu-Christian Studies. The digital version is made available by Digital Commons @ Butler University. For questions about the Journal or the Society, please contact cbauman@butler.edu. For more information about Digital Commons @ Butler University, please contact digitalscholarship@butler.edu. 


\title{
Toward a Fusion of Theological Horizons: Constructivist Reflections and Responses to the Question of Theism in the Yoga Sutra
}

\author{
Graham M. Schweig \\ Christopher Newport University
}

IT is important to explore and disclose how--perhaps even why--we are going to speak about Christian and Yogic theism before conducting an exploration on theism in comparative relation between the two traditions. In this kind of discussion, it is inevitable that working definitions of key terms be provided, particular terms that will be clarified and offered to facilitate the discussion. In this study, I examine and draw from the particular studies of three scholars in the field who address the relationship between Christianity and Yoga in order to illuminate the dialectical tension between a resistence toward and the persistence of the development of a yogic theism. I will argue that Yoga as explicated in the Yoga Sutra possesses a strong and natural theological character, containing a distinct, openended raw theism that necessitates the expansion of the domain and definition of the term.
What must be stated at the outset is that my discussion here is specifically theological, but not in the sense that is commonly understood. This exploration of theism is speaking not merely from within a particular tradition for that particular faith community. Such a person who speaks theology from within a tradition primarily for the benefit of the believers is commonly known as a theologian. But here, this discussion is conducted as a constructivist exercise within comparative theology, with a motive to further an understanding of shared theological moments and connections between traditions, and additionally, to explore the possibility of some greater disclosure of religious truths that might bring theology more into the world of sound intellectual discourse. I would suggest, then, a distinction be made between a theologian and a theologist. The latter, I propose, should point to that person doing theology not only from

Graham M. Schweig is a scholar of comparative religion who focuses on the religions of India. $\mathrm{He}$ is a specialist in bhakti traditions and yoga philosophy, and comparative theology and interfaith dialogue. He did his graduate studies at Harvard University and the University of Chicago, and received his doctorate in Comparative Religion from Harvard. Schweig taught at Duke University, was Visiting Associate Professor of Sanskrit at the University of Virginia, and is a regularly invited lecturer at the Smithsonian Institution. He is currently professor of philosophy and religious studies and director of the Asian studies program at Christopher Newport University, on the Virginia peninsula. His book, Dance of Divine Love: The Rāsa Lìlā of Krishna from the Bhāgavata Purāna, was published by Princeton University Press (2005), Bhagavad Gitā: The Beloved Lord's Secret Love Song, was published by Harper Collins Publishers (2007), and most recently the edited volume, A Living Theology of Krishna Bhakti, by Tamal Krishna Goswami, published by Oxford (2012). Two other books are forthcoming from Columbia University Press: The Bhakti Sūtra: Nārada's Concise Teachings on Divine Love, and Bhagavad Gitā Concordance: Comprehensive Word Reference. 
within a particular tradition but between traditions or even from outside of any tradition: he or she would be known as a theologist. Here the extra-religious realm of theology is engaged to nourish the deeper dimensions of specific traditions, and further, to serve in some small way a global community that still thirsts for a vision of world peace and ultimate meaning.

In her study, T. S. Rukmani sets the stage for understanding ancient Indian theism. Rukmani asserts that ancient Vedic and Upanishadic thought expresses how "everything in the univese" is a form of Brahman, and that it is "possible to meditate or be devoted to a concept of the highest Truth or İśvara in the Vedic tradition." she warns her reader that it may be difficult for persons coming from within the abrahamic faiths to understand ancient India's form of abstract theism.

Truly, in ancient India there is a fluid movement between an abstract, nondescriptive and nonpersonal theism (often refered to as nirguna, or the absolute "without qualities") and the less abstract and more naturalistic, more descriptive and personal theism (saguna, or the absolute "with qualities"). But here theism is preoccupied not so much with the designation of either the one or the other, or even the identity of the theos. Rather it is the relationship of the theos to and within the ultimate reality, or the Brahman, which encompasses all. Hindu India may frustrate the philosopher of religion since it is not strictly a black-and-white distinction. It is not a question of whether or not Brahman is theistic or not, because it is certainly both at the same time. The theistic and nontheistic attributes are fluid rather than rigidly static. And though later sectarian Hindu traditions may argue which one is "higher," or which one arises from the other, or which one is more ultimate, theologically speaking, to do so may eclipse or undercut the divine fullness of Brahman in the process.

Thus Rukmani essentially prepares her Christian or more generally Western reader for encountering a theism that is quite different than those arising from the biblical tradition. Abrahamic theisms consider the identity and personalism of the theos of paramount importance, a conception that by comparison to the Indian theism leans heavily toward a deistic position. In India, we have the interplay between the pantheistic, as it were, and the deistic conceptions, such that the nondescriptive, nonpersonal and the descriptive, personal dimensions of the absolute reality are not only inseparable, but they are necessarily intertwined. This kind of vision requires specifically a theological, and not so much a philosophical, understanding therefore.

In her study entitled “Vijñānabhikṣu's Approach to the İsara Concept in Patañjali's Yogasūtras," Rukmani offers the very well-known statement in the Rig Veda (which too often is translated imprecisely) to further describe the unusual and different character of Indian theism. Her translation of the passage is as follows: "Truth is One. It can be described variously." she cites this passage to illustrate how India has "accommodated an abstract notion of the absolute," and then quotes the Śvetāśvatara Upanișad passage that states "this One is sure not a woman, nor is this One a man, and this one is certainly not a eunich. It is protected by those very bodies whichever It takes up" (S.U. 5.10).

Then Rukmani, throughout her study, contrasts the more enthusiastic interpretations in favor of a yogic theism in the commentaries of several important commentators on the Yoga Sütra with what she feels is a far more reserved or even absent theism in the content of Patañjali's thought or in the aphorisms themselves. she goes into some detail how interpreters of the YS, while leaning toward a greater or lesser conception of theistic yoga, all of them are essentially engaged in an eisegetical reading of the text, claiming more of a theism in the Yoga Sütra than that which is truly there in Patañjali's thought. To effectively show this, Rukmani specifically focuses on the interpretations 
of the word iśvara and the phrase iśvarapranidhāna, and the sütra texts that engage them, from different commentators, and then contrasts these with Patañjali's employment of them in his text showing their relatively less important place in relation to the essential aim of the yogic process or practice.

Gerald Larson, in his study entitled, "Yoga's 'A-Theistic'-Theism: A New Way of Thinking about God," argues that classical Yoga philosophy, or more specifically, Patañjali's conception of God or theism is unique, unlike anything developed in Indian or Western thinking on the subject. Larson seems to be claiming that Indian forms of theism are equally foreign to Yoga's theism as those theisms of the West. (3) To this statement I would say that the Yoga notion of God contrasts Western theological formulations more than Indian ones. Indeed, Larson himself, in his study, draws far more from the Indian philosophers and commentators to Patañjali's Yoga Sūtra and not from Western theologians and philosophers to interpret or understand this peculiar God formulation. It makes perfect sense that Larson would draw primarily from the Indic traditions, since it is out its rich theological soil that the Yoga conception of God grows. Indeed, Rukmani herself constantly dips into the background texts, such as the Vedas and the Upanishads, to further illuminate and support her points in examining commentators' positions in relation to Patañjali's words. Moreover, Rukmani attests to the theistic leanings in Vyāsa's commentary to the Yoga Sūtra, and especially that of the bhakti interpretations of Vijñānabhikșu.

Following Larson's review of the key sūtra texts that focus on a theism, texts 1.23-29, he launches into four types of deconstructive analyses in order to show us what should not be involved or engaged in the theism of Yoga. This deconstructive analysis is the dominant focus of his study. He claims that Yoga theism must undergo a process of (1) de-personalization, (2) deanthropomorphization,

(3) de- mythologization, and (4) deconceptualization. I feel that Larson's deconstructionistic approach in his paper is valuable, because it paves the way for a deeper consideration and view of what theism truly has been as well as what it could develop into being, with the greatest caution against imposing any preconceptions or prejudices derived from the conditioned ways we may view the notion of God as influenced by the powerful Western and Hindu religious or sectarian sources.

Larson suggests that "the manner in which classical Yoga philosophy deals with the notion of God may offer some interesting perspectives for re-thinking the problem of God." While Larson points out that Patañjali "accepts some sort of notion about God," he first wants to deconstruct the God of Yoga to pave the way for a solid re-construction of a genuine theism. Larson wants this God to be "objectless" and resorts to conceptions such as "perfect sattva" and "eternal excellence" and "the pinnacle of omniscience" from Patañjali's thought (YS 1.25). These abstract notions of God that Larson draws from the Sütras may leave us with something that may be, I am suggesting, somewhat more abstract and incomplete than what Patañjali himself offers us in his text. It is interesting that, for the most part, both Rukmani and Larson concentrate on texts 1.23-29 to understand the abstract theism of Yoga, and they do so with great finesse and solid criticism. But I believe that Patañjali offers us more, which I will say more about below.

Andrea R. Jain's study, "The Malleability of Yoga: A Response to Christian and Hindu Opponents of the Popularization of Yoga," in a sense responds to Larson's call to re-construct or perhaps simply to construct anew the Yoga notion of God. Jain calls our attention to the many ways, historically, Yoga has functioned and been applied in the lives of its practitioners, and this type of diversity was certainly exemplified by the early commentators of the Sutra, as Rukmani amply shows. After all, is that not what a 
sūtra is for: the teacher's vision of its timeless wisdom and the application of its teachings according to this vision?

Jain brings out the contemporary problem of conservative Christians in the West who cannot accept Yoga as something to be added to their faith, and conservative Hindus do not accept that Yoga is something that can be removed from their faith. Each of them is against the popularization of Yoga for their own reasons. Jain goes to some trouble to show the diversity within Yoga practices as far back as ancient times, even contrasting the Yoga of the Bhagavad Gitā and the Yoga of the Yoga Sutra of Patañjali. There is no "unchanging essence" of Yoga, Jain asserts, and there is now and always has been a plurality of Yoga.

Jain's study points us to what has always been true of religion in general, or for that matter, for art as well. It is a matter of context. It is a matter of how and whether something is framed for it to be art, or how it is to be seen as meaningful to persons for it to be religious. It has always been something so very personal. For example, because I may see someone in a restaurant drinking wine and eating bread does not necessarily mean they are performing the ritual of the Eucharist! A more likely place would be the sacred context or framing, as it were, of a church. And since such a meal is observed as having taken place at a restaurant, I can safely assume that no such ritual was being performed in that instance.

However, who's to say that this patron of the restaurant did not consider that the wine he was drinking was not the blood of Christ? And that the bread he was eating was not the body of Christ? I would have to ask him or her. And further, do I have a right to tell this person how he or she must regard the wine and the bread? Should I be able to tell this person that he or she has no right to partake of wine and bread outside of a church and without priestly ritual? How Yoga practice is "framed" in the mind and heart of the practitioner is what counts, and not others' assessments or judgments of that practice. Invariably, what is efficacious in Yoga depends upon the reality of the practitioner's situation, that is, the intent, the desire, and the realized achievement of the practitioner. Whether it be the convenient physical or health benefits of Yoga that one is after or the loftiest depths of meditation that reveal one's greatest truth and a vision of ultimate reality, this is a matter of personal decision and realization no matter what the social considerations, pressures or expectations may be.

The concept of theism in Patañjali's Yoga is not only abstract, as has been emphasized by both Rukmani and Larson, but it is flexible (no pun intended). Jain's study reminds us of Yoga's inherent historical elasticity, or its ability to adapt to different religions, different cultures, at different times. The Vedas recognized Yoga practice, the religion of the Upanishads absorbed it, Buddhism and Jainism and even Taoism eventually utilized it, and so it should be no surprise that there are now Jews, Christians, and even Muslims engaging Yoga to enhance the practice of their faiths. And along with this elasticity of Yoga comes all the objections to its adaptations by persons within these faiths who find it inauthentic or wrong for whatever reason. But the important point I wish to make here is that Yoga's theism is certainly not threatening, nor is it doctrinally driven such that Yoga would somehow require one to believe in certain things in order to authentically take up the physical practice of Yoga. It is not as if the tradition of Yoga is endlessly mutable, and we certainly do speak of change but not without some sense of the continuity of tradition. Thus Yoga theism is fluid and Yoga practice is flexible, and these characteristics may account for its easy entrance into various religio-cultural contexts at different points in history.

Jain's insistence that there has never been an "unchanging essence" of Yoga might be slightly extreme. Is she saying that there is nothing consistently central to Yoga practice and thought? Is Yoga so 
elastic and adaptable that Yoga can be anything anyone wants it to be without ever acknowledging something at its core? Is it not a truism almost to the point, in a sort of buddhistic sense, that nothing has an essence and everything forever changes? I question this, because I think this can be taken too far. In the Bhagavad Gitā, Krishna states, "by the powerful effect of time, this yoga was lost . . . in the world" (BG 4.2). So perhaps there is a point at which Yoga can lose something of its essential characteristics, practices, or something at the core of its traditional vision, even as flexible and as adaptable as Yoga has been and still is.

Here, I believe, we might pause for a moment, and carefully consider the meaning of the words truth and reality and the important difference between them. Let us return to Rukmani's engagement of her translation of the statement from the Rig Veda cited above. The Sanskrit for this passage is the following: ekam sad viprā bahudhā vadanti (RV 1.164.46). My translation, which includes the way in which each original word is applied, seeks a theologically sensitive and precise rendition, as the following: "There is one (ekam) reality (sat) about which vibrant persons (viprā) in various ways (bahudhā) speak (vadanti)." The juxtaposition of "the one reality" with "the various ways to speak about it" is itself, I would proffer, a definition of "truth." When humans, or "vibrant persons," desire to grasp that which is ungraspable, they paradoxcially can experience a genuine grasping of the ungraspable, one reality that is attained in Yoga, and that very grasping itself is what I would designate as a person's "truth." Thus supreme reality is one, but the truths that arise from this grasping of it are many, even unlimited. And the Yoga Sūtra explains this: the one who grasps supreme being (grhitr), the grasping of supreme being (grahana), and that which is grasped of supreme being (grähya), come together in the samāpatti (YS 1.41) of samādhi, illuminating the components involved in the revelation of truth.
Because we do not have in English a noun for the adjective true, it is natural that we would resort to the word truth to fill that role. However, in Sanskrit, the word sat and the word satya are more strictly translated as "the true" and "the truth" respectively. The word sat in the theological context really connotes ultimate reality, and since the word grammatically is a present participle of its root "as", which is the verb "to be," the phrase "supreme being" seems most appropriate.

The word sat also in the context of the three auspicious utterances as presented in the Bhagavad Gitā, om tat sat, also is further revealing. The juxtaposition of the utterance tat with the utterance sat immediately delivers a relationship between the specificity of being with the fullness of being, respectively. The fluid relationship between tat and sat is expressed and indicated by the inclusion of the pranava omkāra in this formula. In Indic traditions, one cannot have the tat without the sat, and one cannot have the sat without the tat, and neither is desirable without the fluid movement between the two as om. While the abstract theos of the tat would be stretching the domain of theism to include it, we need to stretch it even further to include the sat, because there is not the one without the other. Moreover, the dialectical movement between the two, what I have referred to here as "fluidity" as it were, must be incorporated in an understanding of Indian theism.

Let us examine even further the om-tatsat dialectic. The Upanishads in general is preoccupied with this fluid movement between the expressions of Brahman as sat, as the nondescriptive, nonpersonal more abstract theism in the fullness of supreme being, and the tat, as the descriptive, more circumscribed more personal theism in the fullness and yet specificity of a supreme being. One of the well-known invocations for several Upanishads expresses the fullness of being, in other words Brahman, in the use of the word pürnam: "Fullness is there (pürnam adah). Fullness is here 
(pūrṇam idam). From Fullness (pūrṇāt), Fullness comes (pūrnam udacyate). From Fullness (pürnasya), when Fullness is taken (pūrṇam ādāya), Fullness (pūrṇam), even so, completely remains (evāvaśisyate)." These invocational words can speak about Fullness, or Brahman, as being "here" or "there". This is expressive of the tat or a recognition of what is fundamentally a theistic distinction. However, in presenting Fullness, the invocation also describes something from which an endless and absolute source of discrete Fullnesses are derivative without diminishing the original completeness or wholeness of Fullness, expressive of the sat. When invoking or speaking of the one, one is also invoking or speaking of the other, and vice versa, and thus the inextricable fluidity and interdependency between the two.

There is a glaring omission in both Rukmani's and Larson's studies that must be pointed out here. Neither acknowledges Patañjali's famous phrase ișta-devata $\bar{a}$ in the Yoga Sūtra. Patañjali recognizes the way the practitioner of Yoga may choose a beloved divinity as a consequence of deep study: "From deep study and recitation of sacred texts to oneself, svādhyāya, one's most desired divinity is experienced fully within Yoga" (svādhyāyād isța-devatāsamprayogah, YS 2.44). The key phrase here is ista-devatā. The word isța can be translated as "loved," "desired," or "chosen." Here, again, we see Yoga's elasticity, its flexibility, and its inclusivity. Patañjali is saying that out of the practive of svādhyāya, which can include many practices beyond the deep study of sacred texts, such as japa meditation, etc., comes the desire to connect with the divinity, in a particular form or image of the divine. This open-endedness is characteristic of Yoga.

This guidance for the practitioner to focus on a "desired [form of the] divine" is in sharp contrast to that of the abrahamic traditions, which have, as a backdrop, the prohibition against imaging the divine. In the Decalogue of the Hebrew Bible, we easily recall the commandment, "You shall not make for yourself an idol ... in the form of anything ... for I the Lord your God am a jealous God ..." (Exodus 20:4-5, NRSV). Thus it is unthinkable to create three dimensional sacred images, artistic images of any kind, or even ideational images or forms of the divine. But in India, the commandment would be quite the opposite: "You shall make for yourself an image that you most love and desire, in the form of anything, for I am your infinite God, and endless are my forms (ananta-rūpa)."

The word devatā is found only once in this text, but that it was engaged at all and how it is engaged is significant. Both Rukmani and Larson, in their own ways, insist that the word iśvara is ultimately synonymous with brahman (which, incidentally, is a term appearing not even once in the Yoga Sūtra). But here we must also understand iśvara as having a relationship with devatā, which is strongly theistic language. Taking the word devatā into consideration only strengthens the picture of theism in the Yoga Sutra, and perhaps invites us to probe further into the text's more subtle expressions of theism than what we might expect. Even though I could imagine how Rukmani, at this point, might give ișta-devatā less importance because it appears in the second sādhanapāda intended for the madhyama-yogin (intermediate practitioner), I would insist that the appearance of this phrase begs to be considered for interpreting the critical phrase iśvara-pranidhāna, which first appears in the samādhi-pāda, the portion of the Yoga Sütra describing the experience of the uttama-yogin (the advanced practitioner).

Furthering an earlier discussion above, devatā is synonymous with truth. A person's truth is what is ultimately loved, revered, honored, and framed, as it were, as the highest reality. It is that person's tat in relation to the sat. Or put in a simple equation, sat divided (or "grasped") by tat equals that person's satya or devatā. Such a vision of devatā must be understood as iśvara, which we might understand as being brahman and devatā, both, no doubt a fluid meaning in the way the term moves 
between the former and the latter. If we examine the word iśvara etymologically, we derive a definition of the term that reveals these two fluid, albeit, components of a specific type of theism. The word breaks down as the two separate words, iśa and vara. The word iśa can mean "governer," "ruler," or "lord," and the word vara can mean "environing," "enclosing," "space," or "circumference." The latter word can have many different meanings, but these are closest to the word's root means from $v r$. While the force of the word brahman leans more toward the state of oneness and ultimacy, and while devatā leans more toward a theos, we might understand that iśvara is the "governer of the circumference (that constitutes ultimate reality)." The word implies the components of a geometic configuration: the circumcenter (iśa) and the circumference (vara), the former representing devatā and the latter representing brahman.

In four of the five total instances in which the word iśvara appears in the first two pādas of the Yoga Sūtra (YS 1.23, 24; 2.1, 32 , and 45), it is coupled with the word pranidhanna, another word that deserves attention. The word is often translated as "dedication," "devotion," or "submission." The Monier-Williams Sanskrit dictionary provides two better glosses for the word that, for some reason, is rarely found in translations of the Yoga Sūtra: "profound religious meditation" and "abstract contemplation." But an etymological, albeit a rather protracted, definition of the word spells these out a little further as, "moving (pra-) deeply (-ni-) into or from the receptacle or seat (-dhāna) [of the heart]." The word dhana relates to what the Upanishads call "the space within the heart," in which the yogin will discover the divine. The fifth and final appearance of the word coupled with isvara is found in YS 2.45: "The perfection of samädhi comes from the profound religious meditation on iśvara" (samādhi-siddhir iśvara-praniidhānāt). Although profound meditation on the divine may be found as a practice in one of the lower limbs of the eight-limbed path, namely the fifth practice of niyama, it is very clear from the samādhi-pāda and from this last instance of iśvara-pranidhāna that it is a practice that is intimately involved at the highest level or perfection of samādhi, the goal of all Yoga.

Yoga, then, involves the continuous uninterrupted movement of consciousness that reaches deeply into the heart where the yogin eventually discovers iśvara, who is the divine purusa (who can be equated with the devatā) and the absolute brahman. Therefore, as I have been demonstrating, the openness and fluidity of the Yoga theism in the Yoga Sūtra allows for Larson's deconstructive advaitic nontheism, while it also accomodates the constructivist theism that one might expect to see from a bhakti theology. From my point of view, the Yoga Sutra, however, presents more of a solid, albeit raw theism, far outweighing a purely abstract, advaitic non-theism.

Let us take Yoga theism even further. A constructivist view of the Yoga Sütra could easily lead one to observe some hint at what we would call grace coming from the divine. Rukmani claims that there is no such divine grace as one would find within Christian traditions. But I believe that Yoga has its own form of grace expressed by the term samapatti, and as described in the text in which the term is defined:

When the turning has ceased, when that which is inborn shines forth like that of a jewel in the one who grasps,

in the grasping and in that which is to be grasped, one stands so near that one attains a state in which [a divine] ointment has been absorbed---

this is Samāpatti, 'coalescence' [of subject and object in meditation].

(YS 1.41)

In this very literal translation, samāpatti is the "falling into a state or condition" (Monier-Williams Sanskrit Dictionary) or what "happens" to the meditating yogin. The consciousness of the meditator is 
compared to a jewel that is so pure, so polished that it can shine forth due to its capacity to catch the light that shines down upon it. The implied element of light in the aphorism's first metaphor of the shining jewel is reinforced by the explicit and tangible substance of an ointment that is put forth in the second metaphor of the text: that state of consciousness in the meditator that absorbs the ointment from the object on which he or she is meditating. This light, this ointment, which comes from a divine object in samapatti, is tantamount to the grace in Yoga. I don't think it is any mistake that one of the most commonly used words for "grace," namely anugraha, or that which "follows the grasping" of truth, is derived from the same root as grahitr ("the one who grasps"), grahana ("the grasping"), and grähya ("that which is to be grasped"), the three elements that become united in Yoga when attaining a state of grace in samāpatti.

It is not within the scope of this study to conduct a thorough vetting of the subtle but certainly present, albeit raw, theistic nuances of the Yoga Sutra. The task that faces us when confronted with the challenge of bringing out any comparative connections and interreligious similarities or commonalities in the theisms of both the Christian and Yoga traditions is a wide enough definition of theism. If we are going to ask if there is a theism in the Yoga Sütra, if there is a God of Yoga, then it behooves us to define the term now more comprehensively and more thoroughly that may prove to expand and deepen the domain of theism precisely because we have a comparative purpose. It is the work of a theologist, as I have defined its unique role above, to move such terms into the comparative arena that casts a wider theological net, accounting for any data that would contribute to an understanding of this category.

A comparative analysis of Christian theism and the theism of Yoga might utilize the ten dimensions I outline below. These ten dimensions are my attempt to give a comprehensive definition of theism because I have found other definitions of the term inadequate for comparative purposes. Such definitions were generally more or less derivative of Greek, Jewish and Christian theological traditions, producing too narrow a definition.

The idea of theism is expounded upon or demonstrated in philosophical discourse, or religious revelation, or theological conceptualization, or a personal or shared understanding, expression, or vision of "the ultimate reality" that possesses any combination or all of the following ten dimensions:

(1) A discrete, unified, perfect and divine supreme being, the eternal self-existent primordial entity, who is often denoted by the word God;

(2) Who is, on some level, apprehended as distinctly personal, presented in descriptive or nondescriptive terms, and who is perceived as having either the intimate and affectionate and/or powerful and grand personified or nonpersonified unlimited forms;

(3) Who may reveal a singular, dual, or multiple number of divine manifestations;

(4) Who may receive gender attributions of feminine, masculine, both or neither, androgynous or neuter designations;

(5) Who is understood as distinguishable from and yet a part of the totality of being;

(6) Who has a relationship with the whole of reality as its source, as its creator, or as its sustainer;

(7) Who, on some level, also contains and fully embraces the totality of being of which such a divine being is the very center and foundation; 
(8) Whose relationship to the totality of being allows such a divine being to be actively and continuously present in the world in various ways, which may include acts of grace, divine intervensions, and special epiphanies;

(9) Who may appear to be limited in appearance when manifesting in an apparently limited form, who not only remains the unlimited divine being, but whose specially manifested form discloses unique aspects of supreme unlimited being for purposes of providentially guiding human beings because of pure grace;

(10) And with whom specifically human beings among all other beings can connect directly or indirectly in various ways according to the naturally occurring or acquired capacity of human receptivity to the divine supreme being.

Perhaps after this attempt to bring out ten dimensions of it, theism could be contrasted to related terms or can be found partially incorporating them, terms such as pantheism, deism, panentheism, polytheism, monism, atheism, etc. My point in presenting these ten dimensions of theism here is to suggest that this could be used as a starting point for comparative analysis of the theism between the two traditions.

Larson himself says that "God is not captured by religion. God cannot be conceptualized by philosophy." And to this I respond in agreement while insisting that there is therefore a special domain for theology. Larson dramatically ends his study with Wittgenstein's words warning us that ultimately language is limiting and words are inadequate for describing such ineffible levels of reality, and that we must resort to silence, schweigen, the German word, ironically, from which my last name is derived. Yet here my attempt has been to move toward anything but silence! Rather, I wish to move toward a fusion of theological horizons, to revise a borrowed phrase from Hans-Georg Gadamer. I wish to move toward more ways, more terms, expanded definitions, greater expressions for the ways to explore and understand the endless depths of theism without fear of committing it to a closed system or eclipsing its power, without fear of reductionisms or reifications, in the hopes that we can discover, first within and then between religious traditions, some shared theological moment that will open up even greater revelations among and between the thirsting human hearts of this world. 